Full-text Available Online at www.ajol.info and www.bioline.org.br/ja

\title{
Heavy metal concentrations in Bottom Sediments of Ikpoba River, Edo State, Nigeria
}

\section{${ }^{* 1}$ MURICE E. IMIUWA; PROSPER OPUTE; ANTHONY E. OGBEIBU}

\author{
Department of Animal and Environmental Biology, Faculty of Life Sciences, University of Benin,
} Benin City, Nigeria

Anthony E. Ogbeibu, ogbeibu@yahoo.com, +2348032943822; eghosa@ uniben.edu, +2348028945470

KEY WORDS: Heavy metal, Bottom Sediments, Ikpoba River, Upstream, Downstream

\begin{abstract}
The concentrations of $\mathrm{Fe}, \mathrm{Mn}, \mathrm{Zn}, \mathrm{Cu}, \mathrm{Pb}, \mathrm{Cr}, \mathrm{Ni}$ and $\mathrm{V}$ were investigated. Samples were collected fortnightly from five (5) stations for four months (July to September, 2009) using Ekman grab operated by hand in shallow water. Station 1 is upstream (Old capitol bridge) and stations 2, 3, 4 and 5 are downstream. The main concentrations (ppm) in stations 1, 2, 3, 4 and 5 are: 931, 117, 812, 679 and $619.7(\mathrm{Fe}) ; 12.11,21.08,9.58,8.64$ and $7.89(\mathrm{Mn})$; 9.90, 12.5, 9.64, 7.07 and $6.62(\mathrm{Zn}) ; 7.88,8.04,5.81,4.34$ and $3.88(\mathrm{Cu}) ; 0.48,0.61,0.36,0.26$, and $0.28(\mathrm{~Pb}) ; 0.19,0.26,0.13,0.12$ and $0.11(\mathrm{Cr}) ; 0.12,0.16,0.08,0.08$ and $0.08(\mathrm{Cd}) ; 0.13$, $0.19,0.13,0.11$ and $0.11(\mathrm{Ni})$ and $0.10,0.15,0.10,0.09$ and $0.09(\mathrm{~V})$. Analysis of variance (ANOVA) showed that Fe (Stations 1 and 2), Cr (Stations 1 and 2) and Cd (Station 2) were significantly different $(\mathrm{p}<0.05)$ between stations. All parameters studied were below FEPA limits. The heavy metal concentrations in bottom sediments of Ikpoba River showed a seasonal pattern of variation. This investigation in comparison with earlier study based on data from Jimoh, 2006; show that $\mathrm{Fe}$ and $\mathrm{Mn}$ concentration increased overtime while $\mathrm{Cd}, \mathrm{Pb}$, and $\mathrm{Cu}$ did not.@ JASEM
\end{abstract}

\section{http://dx.doi.org/10.4314/jasem.v18i1.4}

Description Of Study Area: The study was done along a stretch of the Ikpoba River, a fourth order stream situated within the rainforest belt of Edo State, Southern Nigeria $\left(6.5^{0} \mathrm{~N}, 5.8^{0} \mathrm{E}\right)$. The river takes its rise from the northern ishan plateau and flows in a southwesterly direction in a sleepy incised valley through sandy areas before passing through Benin City and joining Ossiomo River (Ohagi 1983). Basically, the catchment area is a dense rain forest where allochtonous materials of organic matter are derived from the vegetation through surface runoff into the basin. The study area is geologically characterized by coarse sand interspersed with lignite and patches of laterite and sandy clay.

Introduction: Bottom sediment is an integral part of the abiotic components of aquatic ecosystem. It thus provides a living compartment to bottom dwellers which actively engage in its transformation (Tandyrak, 2005). Bottom sediment is to benthos what water column is to a vast array of non-benthos and also to a large extent characterizes the entire aquatic ecosystem due to the condition arising at the water-sediment boundary (Linnik and Zubenko, 2000).

Pollution of natural environment by heavy metals is a worldwide problem because these metals are indestructible and most of them have toxic effects on living organisms, when they exceed a certain concentration. Egborge (1991) related the heavy metal pollution of Warri River to industrialization. Jimoh, (2006 \} investigated the heavy metals content of IKpoba river. $\mathrm{He}$ reported that $\mathrm{Fe}$ was exceptionally high, although all parameters were within the set standard. Ogbeibu and Anagbose (2004) have observed that bottom sediment acts as sink to heavy metals releasing them at the slightest perturbation. Pollution of aquatic ecosystem with heavy metals is ecologically significant because they cannot be eliminated from the reservoir even in the process of self-purification. (Sharma, 2006).

Objectives of the Study To assess the current level of heavy metal concentration with respect to water quality standard by the Federal Ministry of Environment and to upgrade the records available on

* Corresponding Author: ashibudike.opute@uniben.edu, +2348033644134 
the results of the study of heavy metal in bottom sediment of Ikpoba River.

\section{MATERIALS AND METHODS}

Station And Land Use The study area is composed essentially of the secondary rainforest vegetation type which structure is not unconnected with extensive deforestation and other anthropogenic activities. The vegetation is majorly composed of palm trees (Elaeis guinenses), bamboo trees (Bambusa bambusa), Rubber tree, water hyacinth (Eichorrnia carssipes), grasses, and shrubs amongst others. The riparian communities are sparsely populated and their main activities are farming, fishing and palm-wine tapping. Much of the land is also exposed to agricultural activities and municipal waste. Industrial wastes and water from drainage channel are discharged into the river at several points.

Sampling Stations : Samples were collected from five different stations along the course of the river with a grab. Station 1 was taken as a control station for the four other stations.

Stations 1: This is the control station (Plate 1), upstream of the other stations. Marginal vegetation includes bamboo trees. This station is directly under the bridge (old bridge) which is still within the University of Benin Campus (capitol). There were no noticeable activities at this station by riparian communities throughout the period of sampling

Station 2 The second station (plate 2) is about $50 \mathrm{~m}$ downstream of station 1 . Vegetation bordering the bank of this station includes bamboo trees, grasses and aquatic weeds. Occasional fishing is suspected as there were parked canoes along the river at this station.

Station 3 The third sampling station is immediately down-stream of the Ikpoba River dam at Okhoro area. The station is characterized with moderate riffles. Vegetation is almost entirely made up of thick grasses on the bank of the river. Allochtonous input at the station is derived mainly from sacrifices of various sorts performed at the station. Fishing activities is also very high here.

Station 4: The fourth sampling station is located at upper Lawani area. Vegetation here is same as that of the third sampling site. Activities here include making of sacrifices. Animal materials and other food items for the purpose are found in and around the water at this station.
Station 5: The fifth sampling station is under the bridge, along Upper Mission Road. The Station is characterized with fast riffles. There are few aquatic macrophytes like salvinia $\mathrm{sp}$ and water hyacinth (Eichornia crassipes). This station was the lowest in depth during the dry season. The water level however increased when it was heavily flooded during the rainy season. Activities here include making of sacrifices.

Sediment Samples Collection, Preparation And Analysis: Bottom sediment samples were collected fortnightly from the study station from June to September, 2009, using Ekman grab operated by hand in shallow water. Samples were collected, and they were properly taken though the water to prevent dissolution and subsequent loss of some component of the sediment. Sub-samples were collected from the samples in the grab, usually from the core; this was to avoid contamination of sediment with the wall of the grab. Samples were taken in pre-labelled polythene bags to the laboratory for analysis.

Determination of the heavy metals in filtrate was by atomic Absorption Spectrophotometry.

\section{METHODOLOGY}

The method used in the extraction of the heavy metals from the bottom sediment was the Double Acid Extraction Method.(a)Apparatus; (i) $250 \mathrm{ml}$ Plastic Bottle with Stopper (not rubber), (ii) $50 \mathrm{ml}$ Pipette (iii) Plastic funnel, medium, size ; (iv)Filter paper, Whatman No. $42 \mathrm{I}$; (v) Mechanical Shaker (b) Reagent ; (i) $0.05 \mathrm{M} \mathrm{Hcl}$ in $0.025 \mathrm{M} \mathrm{H}_{2} \mathrm{SO}_{4}$; (c) Procedure; (i) $10 \mathrm{~g}$ of bottom sediment was weighed into a $250 \mathrm{ml}$ plastic bottle. (ii) $100 \mathrm{ml}$ of the extracting solution was added, stoppered and shaken for 30 minutes in mechanical shaker. (iii) It was filtered through Whatman filter paper No. 42. (iv)Determination of the trace elements (Fe, Mn, $\mathrm{Zn}$, $\mathrm{Cu}, \mathrm{Cd}, \mathrm{Cr}, \mathrm{Pb}, \mathrm{Ni}, \mathrm{V}$ ) in filtrate was by atomic Absorption Scectrophotometry.

\section{RESULTS AND DISCUSSION}

Like most tropical rivers, the heavy metals concentration of Ikpoba River showed a seasonal pattern of variation. The rank profile of heavy metals indicated that $\mathrm{Fe}$ had the highest mean value (780 1727 ) in all five stations. The mean was significantly high $(\mathrm{P}<0.05)$ in station $1(931 \mathrm{ppm})$ and station 2 (1117ppm) which is located under the bridge. The Fe concentrations were high compared to the concentration observed in an earlier study (163.00 303.00ppm), (Jimoh, 2006). 
This investigation in comparison with earlier study based on data from Jimoh, 2006; show that Fe and $\mathrm{Mn}$ concentration increased overtime while $\mathrm{Cd}, \mathrm{Pb}$, and $\mathrm{Cu}$ did not. $\mathrm{Cr}$ has reduced considerably. The washing off into the river of the bridge by rain is probably the main reason for the high level of $\mathrm{Fe}$ observed here and the high accumulation of organic matter in this region to which metal binds. High concentration of $\mathrm{Fe}$ is not known to have any adverse effects on health (Miroslav and Bashkin, 1999). The availability of $\mathrm{Mn}$ is strongly influenced by the $\mathrm{pH}$ and Eh of the system (Miroslav and Bashkin, 1999). The greater the acidity, the more of the metal will leach out. This also was the case in Fe, hence their correlation.

The mean values of $\mathrm{Zn}(6.9-18.1 \mathrm{ppm})$ were within the recommended allowable limits for bottom sediments of river $(1.5-2000 \mathrm{ppm})$. $\mathrm{Zn}$ concentration was highest in station 2 which is rich in clay as against station 4 which is very Sandy hence the low $\mathrm{Zn}$ concentration at station 4. Miroslav and Bashkin, 1999 has shown that clay substrate and mineral can absorb Zn.

$\mathrm{Cu}$ mean values observed $(2.97-12.5 \mathrm{ppm})$ were below the allowable limit (1-390ppm). Copper forms complexes with dissolved humic material (Sharma, 2006). Thus if humic material is present in soluble form, it acts to increase solubility in water. The mean value is significantly high $(\mathrm{P}<0.03)$ at station 1 and station 2 , this is probably due to high organic content of their region.

$\mathrm{Pb}$ mean values observed $(0.16-1.53)$ was highest at this station (station 2) which is still below the standard for bottom sediment of river $(<1-890 \mathrm{ppm})$. There is no significant difference in concentration in the study stations. Concentration of $\mathrm{Pb}$ in comparison with previous study has not shown any significant change in concentration.

$\mathrm{Cr}$ has the highest mean value $(0.15-0.41 \mathrm{ppm})$ at station 2 . These mean values at station 1 and station 2 show high significant difference $(\mathrm{P}<0.01)$ from other study stations. The mean value is below the specified limits $(0.9-1500 \mathrm{ppm})$. Naturally occurring $\mathrm{Cr}$ is ubiquitous in soil, although their concentration are generally very low (Moroslav and Bashkin 1999). Cd mean value $(0.8-0.16)$ were within the set limit $(<0.01-8 \mathrm{ppm})$. Its anthropogenic source may be from manufacturing of paints, plastics, batteries and in metal plating as well as sewage sludge, grease and smoke (John and Vanlaehoven, (1972). The low level is due to lack of anthropogenic contamination of the river.

$\mathrm{Ni}$ is more abundant than copper and lead. In uncontaminated bottom sediments of rivers and lakes, nickel concentration does not normally exceed 20ppm (Sharma, 2006). Its mean value, $(0.13-0.11)$ were within the allowable limits $(0.1-1520 \mathrm{ppm})$.

Conclusion: The investigation has clearly shown that the heavy metal content of the bottom sediment of Ikpoba River has increased over time. This was considerably high for $\mathrm{Fe}$ and $\mathrm{Mn}$, while a few others like $\mathrm{Cu}$ and $\mathrm{Pb}$ has not changed considerably. Ni has drastically reduced. The concentrations of the heavy metals observed in the study were lower than the specified limits for heavy metals levels in river sediment supporting aquatic life and for drinking. The soil and complex type could have lead to the increasingly high concentration of $\mathrm{Fe}$ and $\mathrm{Mn}$. A major contributing factor is soil humic material (from organic residues). Organic matter may mobilize or immobilize metal in the soil. The solubility of metals which are structural component of organic matter or which form complexes with it, can be determined by the solubility of the associated organic matter, thus metal complexed with the humic material are themselves soluble in high $\mathrm{pH}$ condition (as against our investigation which was acidic). This increase in organic residue could have led to a proportionate increase in $\mathrm{Fe}$ and $\mathrm{Mn}$.

Table 1: Comparison of the concentration of the heavy metals of the bottom sediment with earlier investigation of Ikpoba River.

\begin{tabular}{ccl}
\hline METALS & $\begin{array}{l}\text { IKPOBA RIVER, } \\
\text { 2006 (mg/kg) }\end{array}$ & $\begin{array}{l}\text { IKPOBA } \\
\text { RIVER, } \\
\text { 2009 }(\mathbf{p p m})\end{array}$ \\
\hline $\mathrm{Fe}$ & $163.00-303.00$ & $333.1-1727.1$ \\
$\mathrm{Mn}$ & - & $2.48-12.34$ \\
$\mathrm{Zn}$ & $11.00-106.98$ & $1.00-18.07$ \\
$\mathrm{Cu}$ & $6.00-6.44$ & $1.98-12.48$ \\
$\mathrm{~Pb}$ & $5.10-8.00$ & $0.03-1.53$ \\
$\mathrm{Cr}$ & $0.01-3.24$ & $0.07-0.410$ \\
$\mathrm{Cd}$ & $1.00-2.00$ & $0.044-0.210$ \\
$\mathrm{Ni}$ & - & $0.047-0.31$ \\
$\mathrm{~V}$ & - & $0.38-0.29$ \\
\hline
\end{tabular}

MURICE E. IMIUWA; PROSPER OPUTE; ANTHONY E. OGBEIBU, 
Source: Jimoh, 2006

Table 2: Mean, Minimum and Maximum values of heavy metal concentrations in the study stations June-

\begin{tabular}{|c|c|c|c|c|c|c|c|c|c|c|}
\hline Parameters & Station 1 & & & Station 2 & & & Station 3 & & & P-value \\
\hline & $\overline{\bar{x}} \pm \mathrm{SD}$ & Min & Max & $\overline{\bar{x}} \pm \mathrm{SD}$ & Min & Max & $\overline{\bar{x}} \pm \mathrm{SD}$ & Min & Max & \\
\hline $\mathrm{Fe}$ & $931.4^{\mathbf{A}} \pm 270$ & 650 & 1442 & $1117^{\mathbf{A}} \pm 322.4$ & 780 & 1727 & $812.3^{\mathbf{B}} \pm 479$ & 333 & 1606 & $\mathrm{P}<0.05$ \\
\hline $\mathrm{Mn}$ & $12.11^{\mathrm{B}} \pm 4.18$ & 5.12 & 16.9 & $21.08^{\mathbf{A}} \pm 9.87$ & 5.56 & 32.7 & $9.58^{\mathrm{B}} \pm 6.39$ & 2.48 & 18.6 & $\mathrm{P}<0.01$ \\
\hline $\mathrm{Zn}$ & $9.90 \pm 2.95$ & 6.68 & 13.6 & $12.5 \pm 4.35$ & 6.9 & 18.1 & $9.64 \pm 4.48$ & 4.72 & 14.7 & $\mathrm{P}>0.05$ \\
\hline $\mathrm{Cu}$ & $7.28^{\mathbf{A}} \pm 3.05$ & 2.56 & 10.9 & $8.04^{\mathrm{A}} \pm 3.43$ & 2.97 & 12.5 & $5.81^{\mathbf{B}} \pm 2.57$ & 2.11 & 8.97 & $\mathrm{P}<0.05$ \\
\hline $\mathrm{Pb}$ & $0.48 \pm 0.53$ & 0.04 & 1.2 & $0.61 \pm 0.63$ & 0.06 & 1.53 & $0.36 \pm 0.38$ & 0.03 & 0.90 & $P>0.05$ \\
\hline $\mathrm{Cr}$ & $0.19^{\mathbf{A}} \pm 0.08$ & 0.12 & 0.32 & $0.26^{\mathbf{A}} \pm 0.12$ & 0.15 & 0.41 & $0.13^{\mathbf{B}} \pm 0.04$ & 0.08 & 0.18 & $P<0.01$ \\
\hline $\mathrm{Cd}$ & $0.12^{\mathbf{B}} \pm 0.04$ & 0.08 & 0.20 & $0.16^{\mathbf{A}} \pm 0.05$ & 0.09 & 0.21 & $0.08^{\mathrm{C}} \pm 0.03$ & 0.04 & 0.11 & $P<0.01$ \\
\hline $\mathrm{Ni}$ & $0.13 \pm 0.03$ & 0.09 & 0.18 & $0.19 \pm 0.08$ & 0.08 & 0.31 & $0.13 \pm 0.06$ & 0.06 & 0.23 & $\mathrm{P}>0.05$ \\
\hline V & $0.10 \pm 0.03$ & 0.07 & 0.15 & $0.15 \pm 0.08$ & 0.06 & 0.29 & $0.10 \pm 0.06$ & 0.04 & 0.20 & $\mathrm{P}>0.05$ \\
\hline THC & $3.27 \pm 1.36$ & 1.60 & 5.10 & $4.01 \pm 1.75$ & 1.90 & 6.3 & $2.59 \pm 1.24$ & 1.50 & 4.30 & $P>0.05$ \\
\hline
\end{tabular}

Similar letter indicates no significant different at $\mathrm{P}>0.05$.

Note:

$\begin{array}{cccc}\mathrm{P}<0.001, & \mathrm{P}<0.01 & - & \text { Highly significant } \\ \mathrm{P}<0.05 & & - & \text { Significant } \\ \mathrm{P}>0.05 & & - & \text { Not significant }\end{array}$

Table 3: Mean, Minimum and Maximum values of heavy metal concentrations in the study stations June- September, 2009. (Stations 4 and 5)

\begin{tabular}{llllllll}
\hline Parameters & Station 4 & & & Station 5 & & P-value \\
\hline & $\bar{x} \pm$ SD & Min & Max & $\bar{x} \pm$ SD & Min & Max & \\
$\mathrm{Fe}$ & $679^{\mathbf{B}} \pm 175.6$ & 478 & 883 & $619.7^{\mathbf{B}} \pm 95.7$ & 503 & 763 & $\mathrm{P}<0.05$ \\
$\mathrm{Mn}$ & $8.64^{\mathbf{B}} \pm 2.94$ & 3.45 & 12.3 & $7.89^{\mathbf{B}} \pm 3.18$ & 2.81 & 12.3 & $\mathrm{P}<0.01$ \\
$\mathrm{Zn}$ & $7.07 \pm 4.67$ & 1.00 & 12.2 & $6.62 \pm 3.74$ & 2.6 & 11.6 & $\mathrm{P}>0.05$ \\
$\mathrm{Cu}$ & $4.34^{\mathbf{C}} \pm 1.53$ & 1.98 & 5.98 & $3.88^{\mathbf{C}} \pm 1.42$ & 2.01 & 6.00 & $\mathrm{P}<0.05$ \\
$\mathrm{~Pb}$ & $0.26 \pm 0.25$ & 0.04 & 0.64 & $0.28 \pm 0.28$ & 0.03 & 0.66 & $\mathrm{P}>0.05$ \\
$\mathrm{Cr}$ & $0.12^{\mathbf{B}} \pm 0.04$ & 0.07 & 0.17 & $0.11^{\mathbf{B}} \pm 0.02$ & 0.10 & 0.15 & $\mathrm{P}<0.01$ \\
$\mathrm{Cd}$ & $0.08^{\mathbf{C}} \pm 0.02$ & 0.05 & 0.11 & $0.08^{\mathbf{C}} \pm 0.02$ & 0.06 & 0.10 & $\mathrm{P}<0.01$ \\
$\mathrm{Ni}$ & $0.11 \pm 0.05$ & 0.06 & 0.20 & $0.11 \pm 0.05$ & 0.05 & 0.17 & $\mathrm{P}>0.05$ \\
$\mathrm{~V}$ & $0.09 \pm 0.05$ & 0.05 & 0.17 & $0.09 \pm 0.05$ & 0.04 & 0.15 & $\mathrm{P}>0.05$ \\
$\mathrm{THC}$ & $2.47 \pm 1.23$ & 1.40 & 4.6 & $2.61 \pm 1.17$ & 1.4 & 3.90 & $\mathrm{P}>0.05$ \\
\hline
\end{tabular}

Similar letter indicates no significant different at $\mathrm{P}>0.05$.

$$
\begin{array}{cccc}
\mathrm{P}<0.001, & \mathrm{P}<0.01 \quad- & \text { Highly significant } \\
\mathrm{P}<0.05 & & - & \text { Significant } \\
\mathrm{P}>0.05 & & - & \text { Not significant }
\end{array}
$$

\begin{tabular}{|c|c|c|c|c|c|c|c|c|c|c|}
\hline & $\mathrm{Fe}:$ & $M n:$ & $\mathrm{Zn:}$ & $\mathrm{Cu}:$ & $P b:$ & $\mathrm{Cr}:$ & $C d:$ & $N i:$ & $V:$ & THC: \\
\hline Fe: & 1.0000 & & & & & & & & & \\
\hline Mn: & 0.6950 & 1.0000 & & & & & & & & \\
\hline Zn: & 0.7541 & 0.7983 & 1.0000 & & & & & & & \\
\hline $\mathrm{Cu}:$ & 0.6611 & 0.8747 & 0.7384 & 1.0000 & & & & & & \\
\hline $\mathrm{Pb}:$ & -0.0232 & 0.0655 & -0.2048 & 0.0795 & 1.0000 & & & & & \\
\hline Cr: & 0.0611 & 0.1199 & -0.1262 & 0.0465 & 0.7990 & 1.0000 & & & & \\
\hline Cd: & -0.0214 & 0.0955 & -0.1226 & 0.0451 & 0.5798 & 0.8868 & 1.0000 & & & \\
\hline $\mathrm{Ni}:$ & 0.5187 & 0.7505 & 0.8153 & 0.6053 & -0.3924 & -0.1785 & -0.0457 & 1.0000 & & \\
\hline \multicolumn{11}{|c|}{$\begin{array}{l}\text { BOLD LETTERS INDICATES } \\
\text { SIGNIFICANT }\end{array}$} \\
\hline $\mathrm{df}=$ & $\mathrm{r}_{2(0.05)}=$ & & & & & & & & & \\
\hline
\end{tabular}

Table 4: Correlation co-efficient values of heavy metals of the study area June-September, 2009. 
Table 5: Inter-station comparison of heavy metals concentration in bottom sediment of Ikpoba River, June-September 2009

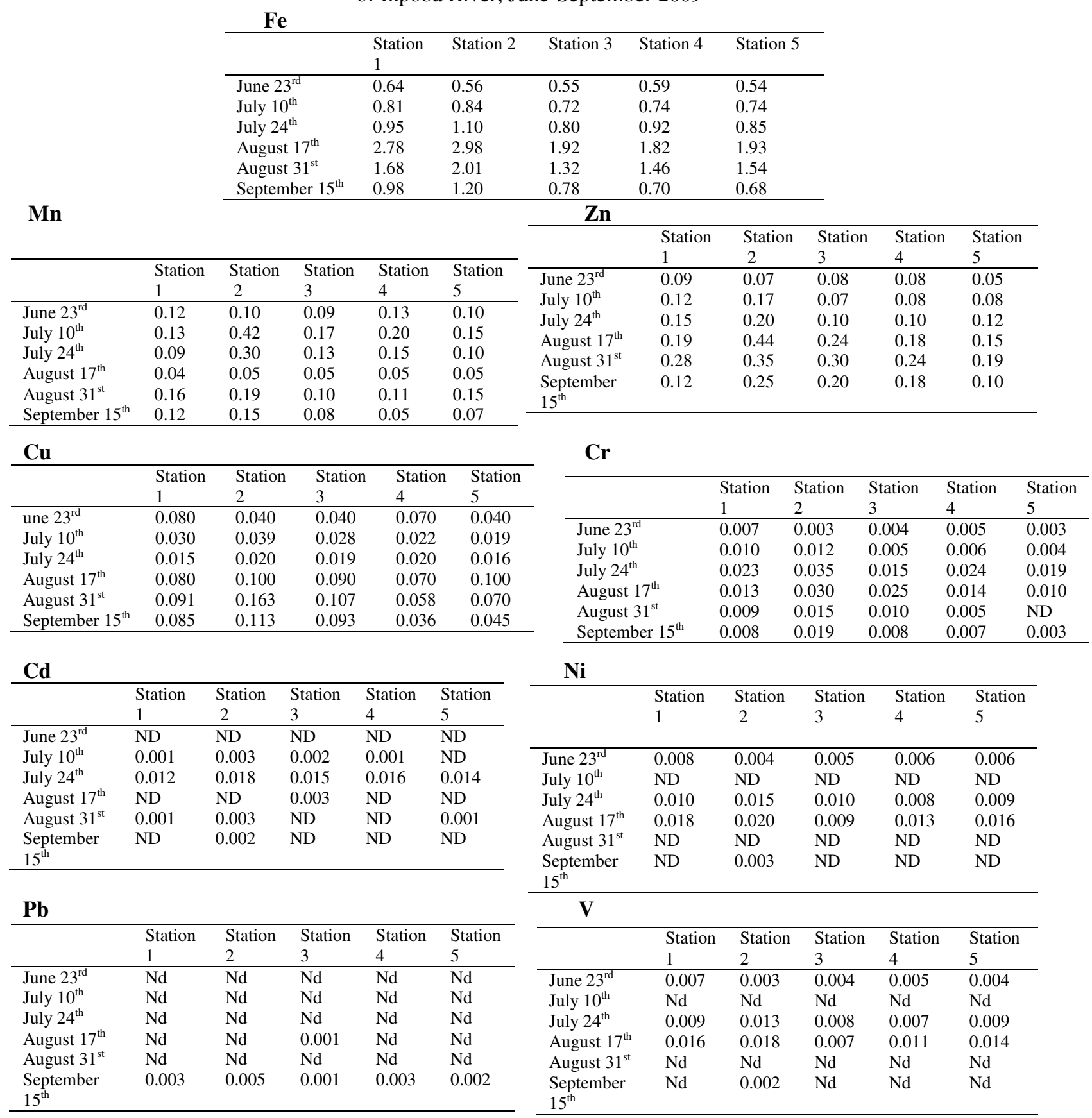




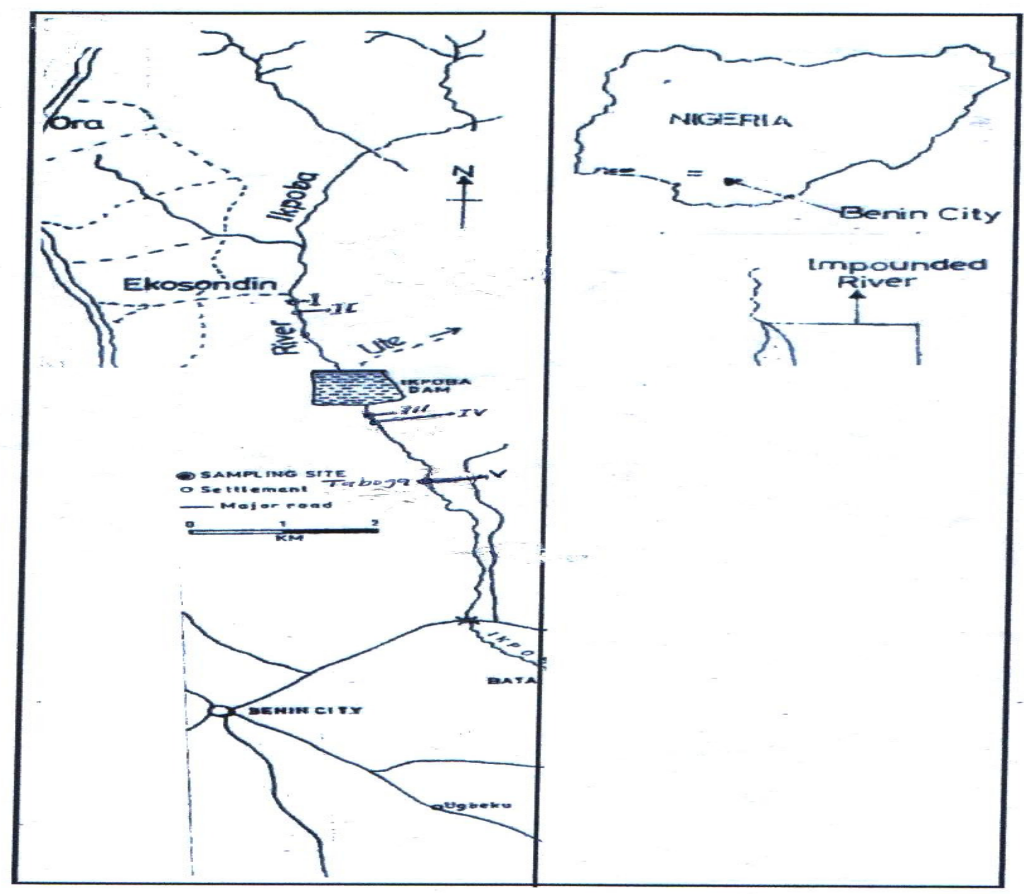

Fig 1: Map of the study area (Ikpoba River) showing study stations

\section{REFERENCES}

Egborge, A.B.M. (1991). Industrialization and heavy metal pollution in Warri. $32^{\text {nd }}$ Inaugural lecture. University of Benin. Benin City. Environment. Spring-berlag, Berlin. Heidel berg, New York. 486PP.

Federal Environmental Protection Agency, (FEPA) (1991). National Environmental Protection. Published by Federal Government Press. Lagos, Nigeria

Jimoh, H.E. (2006). Surface water physico-chemical and bottom sediment quality of the Ikpoba River, Benin City and stated Recovery after five (5) years of Dredging. B.Sc. Thesis, University of Benin, Benin City. 82pp.

Miroslav, R. and Bashkin, V.N. (1999). Practical environmental analysis. Royal Society of Chemistry, Madison. 466pp.
Ogbeibu, A.E. and Anagboso, M.U. (2004). Baseline limnological investigation of the Utor river in Esan Southeast, Edo State, Southern Nigeria. 1: Physical and chemical hydrology. Tropical Freshwater Biology. 12/13:45-62.

Sharma, B.K. (2006) Environmental Chemistry. Goel publishing house, meerut. 1380pp

Tandyrak, R., Lossow, K. and Gawronska, H. (2001). Long-term changes of environmental condition in a lake restored by phosphorus inactivation. Limnol. Rev. 2:399-406

Linnik P. M. and I. B. Zubenko (2000). Role of bottom sediments in the secondary pollution of aquatic environments by heavy-metal compounds. Lakes and Reservoirs: Research and Management. 5 (1): 11-21 